\title{
講義および解說
}

\section{熔接継手の靜的强度 (2)}

\section{3 側面隅肉熔嬨継手}

側面隅肉熔接の忘力分猚は理諭的には次の 2 つ分けて 侤号れている。すなわら

1）熔接の長手方向に沿。ての剪断芯力の分布一ての場 合には隅肉の形状は考虑せず, 隅肉は比较的長い理想化し た剪断面として働くと仮定する.

2）隅肉三角形断面内の态力分布一この場合治実際の隅 肉三角形の変形を取扱う。

第 2 の問題については研究が非常に少なくU.V. Gardena 氏1)などが試みているとすぎず，結果も見るべきすがな くな招研究の必要がある。第 1 の問題炕ついては H.W. Troelsch 氏2)，F. Bleich 氏i3)，W. Hovgaard 氏4など多く の研究者が試みて怙り，剪断応力の分布性不均一で双曲線 函数の形をとるという結果に大体一致している．もちろん

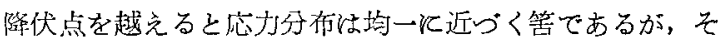
のような塑性状態を考虑した解析は行われていない。この 場合多くの研究者は次江示すような仮定を用いている.

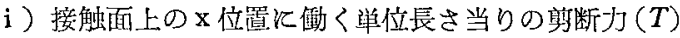
は相刘的变位 $(\lambda)$ 飞比例士る（比例常数 =Detrusion Ratio $=D$ ). すなわち $T=D \cdot \lambda$ あるい性相対的变位 $(\varepsilon)$ 结剪断

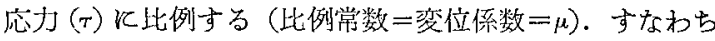

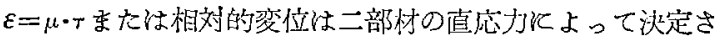
れる.

ii）剪断応力のみが喉断面上飞均一飞分柿し，ポアソン 比炕よる効果は無視できる.

iii）曲げモーメントルよる直応力は無視する.

Detrusion Ratio を用いて側面湡肉熔接を研究した人に 洁 H. W. Troelsch $氏^{2}$, F. Bleich 氏 ${ }^{3)}$, E. Callandreau

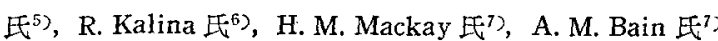
などがありいずれも $\cosh$ 型の剪断店打分布式を得てい る. Detrusion Ratio は H. W. Troelsch 氏飞よれね゙単䏓 熔接コワサの尺度であり，その值は熔接の条件（形状招よ び寸法）によって異なり，实験的に決定しなければならな い.このDが決定されるときは理諭式上り韵断応才の分有 を求めることができるが，Dの值いか炕よって塑断応力の
太王省 三 郎*

分布状態がかな変ってくるので，正確にかつ愹接条伴ど と飞求める必要がある．例面隅肉熔接の応力分布を理論的 飞計算するにはDを用うるのが妥当と考光られているから Detrusion Ratio の研究はぜひ共必要であるにも拘らず， 現在までD関する系統的研究なあまり行われていないよ うである.いままで求められた Dの值は $0.4 \times 10^{6} \sim 1.5 \times$ $10^{6} \mathrm{~kg} / \mathrm{cm}^{2}$ の範囲炕ある. 要する化 Detrusion Ratio 恃理 諭と実験結果との間炕なんらかの関係を磪立するため汇実 験常数として導入されたものであるが，一方 W. H. Weiskopf と M. Male 雨氏8/はこれを理論的に研究している. また変位係数は W. Hovgaard 氏4，P. Fillunger 氏9)など が使用しているがこれは Deteusion Ratio走置換え得るも のである.

これらを使った双榣型の応力分有式から得られる主な 結果㹥次の如くである。

1）断面剩の大なる方の部材の端部《近い熔着金属端部 飞最大の兽断底力を生ずる。

2）平均応力以下の庶力有する部分が平均応力以上の 忍力を有する部分より長い

3）剪断広力分标怙最小点を中心として対称をなし，雨 端部の応力蚛中心部の応力ょり高い。

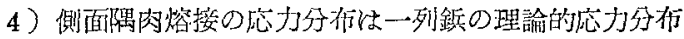
と著しく類似している。

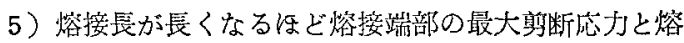
接中央部の最小剪断忍力の此が大となり，また端部の最大 䙷断応力は燃接長をある程度以上增加しても殆ど隇少しな W.

このととは嗬重 $\mathrm{P}$ 亿対して長さ $l$ が適当な㭙, 荷重 $2 \mathrm{P}$ 飞坟しては長さ $2 l$ で端部大応力がより大となり不都合 なことを示すものである ${ }^{10}$.

これらの結夥甠歪計を用うる方法, 光弾性法,ゴム模型

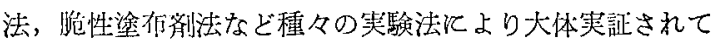
いる，従来は主として機椷的歪計が用いられてきたが䉓気 的歪計，光塑性法などによれげさら飞正確な結果が期待さ れ上弓．末た三次元の応力分们関しては三次光弾・塑性 法を用いて求めることができる管であるが，末だ行われて いないようである。

破壊強度飞関する実験絬果より得られた結果を総括する

* 正負 鉄道技術研究所 


\section{と次の如くである.}

1）側面隅肉熔接の破壊は端部より始まると考学られる が, 跾密には明らか火なっていない。

2）強度（最大喉応力）以熔接長の增加と共飞減少する （理論と合致する）という結果が多いが（F. R. Freeman 氏 ${ }^{11)}$, H. E. Groue氏 ${ }^{12}{ }^{22}$, E. Gaber氏 ${ }^{13)}$, Adhesives Research Committee ${ }^{14}$, E. P.S. Gardner 氏 ${ }^{15}$ など), 降伏を たは破壊が板の方烧炕起っているとともあり，断定はで きない。

3）脚長の増加と共良大喉応力は減少する傾问がある (E. Höhn 民16 ${ }^{16}$, S. Bryla氏 ${ }^{17}$ ， R. R. Blackwood 氏 ${ }^{18)}$,

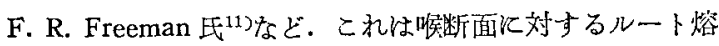
込の比率が变化するたでああると考えられる. 従って許容 応力として一定の值をとると大きい隅肉詨するよりむ小 さい隅肉汶する方が安全率はや小大となる.

4）側面隅肉の最大唉応力以縮の方が引張よりもや小 高い（F. R. Freeman 氏11)，N. C. Kist 氏19)など).

5）側面隅肉の最大喉応力《前面隅肉の最大喉灾力の 大体 80\%（60 100; 武藤氏 20 の理論で性 85\%)，30〜40 $\mathrm{kg} / \mathrm{mm}^{2}$ 程度である。

6) 当板の幅と熔接長の比は設計土 1 以下が有利である (C. H. Loffan (21)).

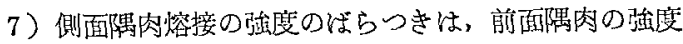
のぼらつきと突合わせ熔接の強度のばらつきとの中間炕 る (G. A. Hankins A.F. C. Brown 氏22).

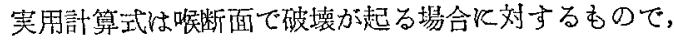
剪断応力は隅肉全長にわたり，かつ喉断面上でも均一飞分 布すると仮定して荷重と喉断面積の比を剪断忍力としてい

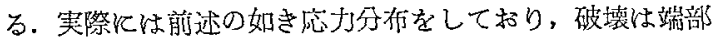
より始まると考光られるが，一般汅はこのような影響は無 視し，破壊荷重は大体燃接長炕比例して增大するとして差 支党ないことが多い，但し DIN 4100 で側面隅肉の特性 を洘甞して，その連続長さを喉原の40倍以上飞するととを 許していない，また隅肉脚長が大きくなると破壤心力がや

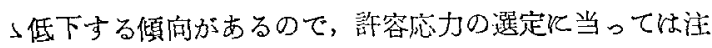
意を要する。

次㵊近の興味ある研究について述べる。

1) P. J. Palmer 氏の研究 ${ }^{23}$

一般に従来の理諭24で前述の上らに主板および当板の

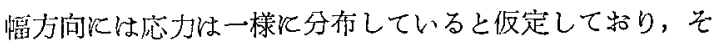
れらの解で怔一つの部材から地の部材への荷重の変化の割

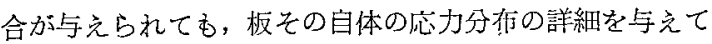
呿らず，乙たがって度力集中が見逃さはている. P. J. Palmer 氏注理諭的飞当板括よび主板の㐫力分布を見出し，こ の応力分布から熔接線を通しての荷重の変化の割合を推定 し，熔着部の剪断力を推定している.

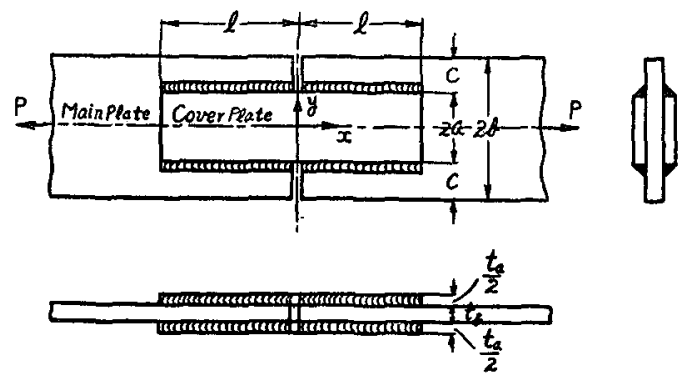

Fig 1. Geometry of side-welded cover plate

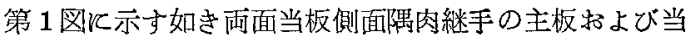
板の綐方向の直応力分布を shear-lag method Kよって求 める.ここで用いた仮定江次の2つである。

i) 問題は二次元問題とし, 板の厚さ方向《结力の值 は変化しない。

ii）横方向の応力と歪は比較的重要でなく無視しうるも のとする(すべての横方向の变位が零であることを意味し 板は横方向沈用体と見なす）。

縦直応力 $\left(\sigma_{x}\right)$ と縮変位による剪断応力 $\left(\tau_{x} y\right)$ との釣合 式性

$$
\frac{\partial \sigma_{x}}{\partial x}+\frac{\partial \tau_{x y}}{\partial y}=0
$$

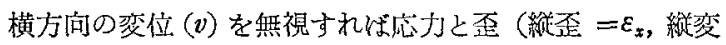
位住よる韵断歪 $=\gamma_{x} y$ ) の関係は

$$
\left.\begin{array}{l}
\varepsilon_{x}=\frac{\sigma_{x}}{E}=\frac{\partial u}{\partial x} \\
\gamma_{x}=\frac{\tau y y}{G}=\frac{\partial u}{\partial v}
\end{array}\right\}
$$

である.

いま $\sigma_{x}$ 呿よび $\tau_{x} y$ を（1）式代大すると縦方向の资位 (u）をきめる微分方程式は次の如くなる.

$$
\frac{\tilde{\sigma}^{2} \mathrm{u}}{\partial x^{2}}+\frac{\mathrm{G}}{\mathrm{E}} \frac{\partial^{2} u}{\partial y^{2}}=0 \cdots
$$

これを变形すれは Laplace の微分方程式となる。 まず当板について考党る。境界条件は

$$
\left.\begin{array}{l}
x=l: \sigma_{y}=0 \\
x=0: \tau_{x}=0
\end{array}\right\}
$$

$u$ 飞対しては（3）式が満足され，合态力が境界条件を蔳足 するならばいは次式で与光られる.（suffixの a, bi, bo は 各当板, 主板の当板内部, 主板の当板外部を意味する）

$$
\begin{array}{r}
u_{a}=\sum_{n=1,2,3, \ldots}^{\infty} \mathrm{A}_{2 n-1} \cdot \sin (2 \mathrm{n}-1) \frac{\pi x}{2 l} . \\
\mathrm{s} \cdot \cos h(2 n-1) \frac{\pi k y}{l 2} \ldots \ldots \ldots \ldots . . .
\end{array}
$$

ここに $k=\sqrt{E / G}, A_{2 n-1}=$ 当板の応力を決める係数

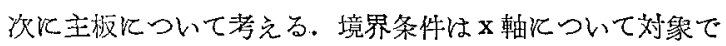

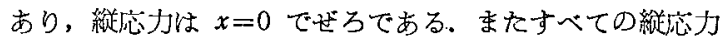
は $y=\mathrm{a}$ では連続であるはずである。これらの境界条件を 


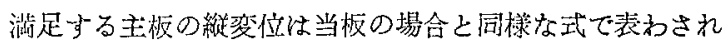
る.

$$
\left.\begin{array}{rl}
u_{b i}= & u_{l}+\sum_{n=1}^{\infty}(-1)^{n} \mathrm{~B}_{2 n-1} \cdot \cos (2 n-1) \frac{\pi x}{2 l} \cdot \\
& \cosh (2 n-1) \frac{\pi k y}{2 l} \cdots \cdots \cdots(y=0 \sim a) \\
u_{b 0}= & u_{l}+\sum_{n=1}^{\infty}(-1)^{n} \cdot C_{2 n-1} \cdot \cos (2 n-1) \frac{\pi x}{2 l} \cdot \\
& \cosh (2 n-1) \frac{\pi k(b-y)}{2 l} \cdots \cdots(\mathrm{y}=\mathrm{a} \sim \mathrm{b})
\end{array}\right\}
$$

$B_{2 n-1}, C_{2 n-1}$ はとれぞれ主板の当板附部特よび外部の心力 を決める係数で $y=a$ 飞招いて綐応力挌よび変位が連続で あるととから汽定される。すなわち

$$
\left(\sigma_{b} j\right)_{y=a}=\left(\sigma_{b o}\right)_{y=a}
$$

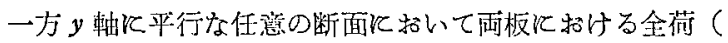
$P=$ 板火作用する方䋛方向の全引張荷重).

$$
+2 \int_{0}^{a} \sigma_{a} \cdot t_{a} \cdot d y+2 \int_{0}^{a} \sigma_{b i} \cdot t_{b} \cdot d y+2 \int_{a}^{b} \sigma_{b 0} \cdot t_{b} \cdot d y=\mathrm{P} \cdots
$$

上式中の応力の項は (2)K(5)と（6)を代入すれば次の式 で表わされるものである。

$$
\begin{aligned}
\sigma_{a}= & +E \sum_{n=1}^{\infty} A_{2 n-1} \cdot(2 \mathrm{n}-1) \cdot \\
& \frac{\pi}{2 l} \cdot \cos (2 n-1) \cdot \frac{\pi x}{2 l} \cdot \cosh (2 n-1) \frac{\pi k y}{2 l} \\
\sigma_{b l}= & -E \sum_{n=1}^{\infty}(-1)^{n} \cdot \mathrm{B}_{2 n-1} \cdot(2 n-1) \cdot \\
& \frac{\pi}{2 l} \sin (2 n-1) \cdot \frac{\pi x}{2 l} \cdot \cosh (2 n-1) \frac{\pi k y}{2 l} \cdot \\
\sigma_{b 0}= & -E \sum_{n=1}^{\infty}(-1)^{n} \cdot C_{2 n-1} \cdot(2 n-1) \frac{\pi}{2 l} . \\
& \sin (2 \mathrm{n}-1) \cdot \frac{\pi x}{2 l} \cosh (2 n-1) \frac{\pi k(b-y)}{2 l}
\end{aligned}
$$

係数 $A_{2 n-1}, B_{2 n-1}, C_{2 n-1}$ は境界策件括よびエホルギ法に よって汰定される。

数値計算例アルミニウム合金構造物

$$
\begin{cases}\text { 主板 } & \text { 幅 } 8 \mathrm{in}, \text { 厚さ } 1 / 2 \mathrm{in}, \\ \text { 当板 幅各 } 6 \mathrm{in}, \text { 長さ } 10 \mathrm{in}, \text { 厚さ各 } 1 / 2 \mathrm{in}\end{cases}
$$

当板括上び主板の両方の荷重の变化况縦方向の $x=0,0.25 l$, $0.50 l, 0.75 l$ 打よび $x=1.00 l$ で沈定し第 2 図至得た。これ は何重が一部材から他部材へ移るととを示し，この荷重の

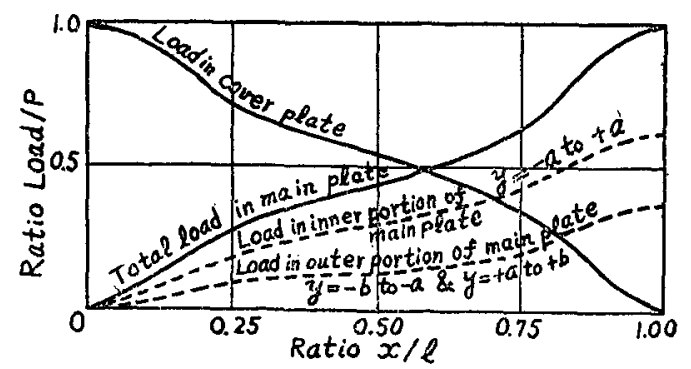

Fig 2. Transfer of load between main plate and cover plate

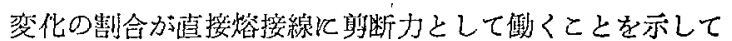
いる，むし剪断応力を必要とするなら（2），(5)，(6) 既から得られる。

第3 図は D H. Wade 氏 ${ }^{25}$ 名行った䒠駼結果と理諭値 そよる縦忍力の詳細な此较であるが雨者な殆ど合致してい る.

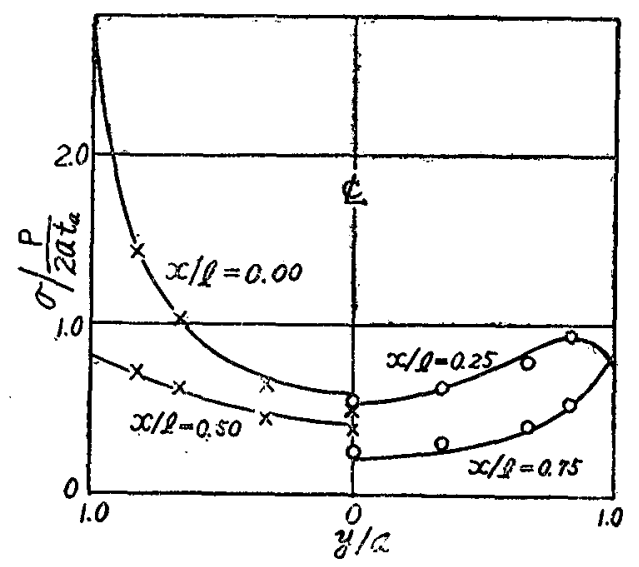

Fig 3. Comparison of theory with experiment : distribution of longitudinal stress cover plate

\section{2) A. M. Mackie 氏の実験 ${ }^{6)}$}

揢接継手の応力解析飞必要な熔接の基本的特性, 破填荷 重执よび荷重一変形特性は笑合わせ执上び前面隅肉では容 易に求められるが，側面隅肉熔接の場合《は従来の試験片

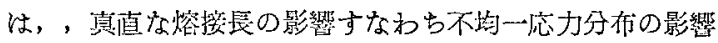

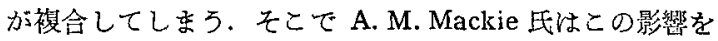
なくするような側面隅肉熔接の新しい試験片を考案した。 これは外侧環状板之内側円板とできて括り，それらを然端、 の連続熔接で贸合したものであって，一方の板を保持し他 方にトルクを加えて熔接に均一伈力を与えるものである.

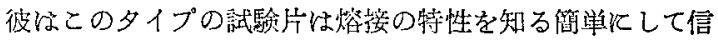
頼し得る方法であり，正礶さが得られることから熔接法の

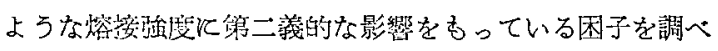
るのに有用であるうと述心，適当な測定法を用いれば熔接 綖手の解析を一段と進めるデータが得られるであるうと結 んでいる。しか乙試験機，試験片などの詳細な寸法が示さ れて特らず，2種の A1 合金で得た結果も簡単飞述べられ ているとすぎい。

3) F. Koenigsberger, H. W. Green 両氏の実験27 ${ }^{282}$ アングルをガゼット板炕熔接する場合，設計者の中反は

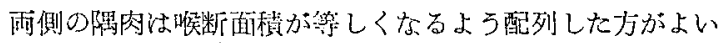
と考党ているものもいるが，特に米函招よびヨーロッパで

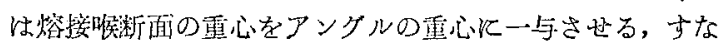
わら両側の熔接の喉断面樍をこれぞれアングルの重心から の距離に反比例させるのがよいと洘觉られている。これを 


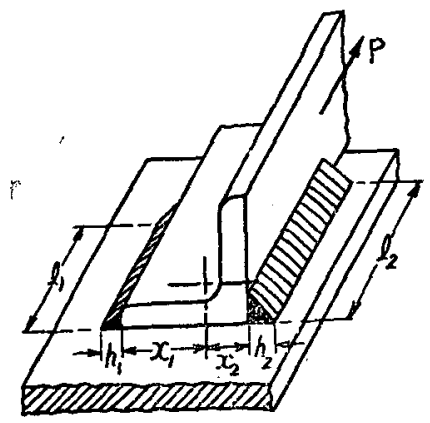

Fig 4. Arrangement of fillet weld: throat areas proportional to distance from centroid of angle section

式に婊わせぼ次のようになる（第 4 図参照）。

$$
\begin{aligned}
& \sigma_{s}=\frac{P}{A_{w_{1}}+A_{w 2}}=\frac{P}{0.706\left(l_{1} h_{1}+l_{2} \overline{h_{2}}\right)} \\
& A_{w w_{1}}: A_{w_{2}}=x_{2}: x_{1} \\
& l_{1} h_{1}=\frac{1.414 P}{\sigma_{s}} \times \frac{x_{2}}{x_{1}+x_{2}} \\
& l_{2} h_{2}=\frac{1.414 P}{\sigma_{3}} \times \frac{x_{1}}{x_{1}+x_{2}}
\end{aligned}
$$

F. Koenigsberger, H. W. Green 雨氏纪この問題を静荷 重招よひ疲学荷重飞分けて実験している，第 5 図が静荷重 試験片て (a) 恬附側の熔接を等しくしたもの，(b) 物よび (c) は熔接の重心とアングルの重心を一致させたものであ る. 実験の結果江筑 1 表に示す如く静荷重の場合には熔接 の配列は荷重伝達能力（强度）飞影響せず, また短い方の 揢接の長手方向位置も㓌度には関係せず応力の増加状態を 変兄るのみであった.（な挌疲学試験で揢接の重心とア ングルの重心とを一致させた継手の方が，アンクル両側の

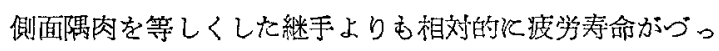

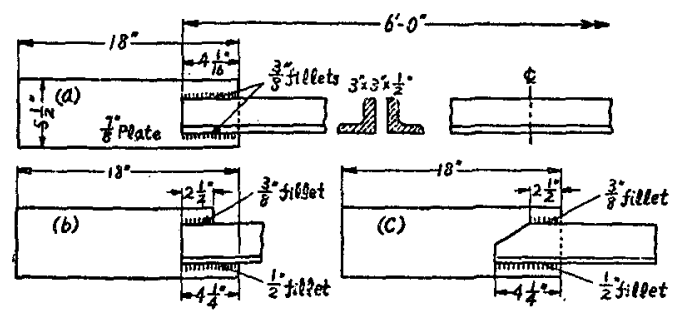

Fig 5. Double angle specimens for static loading tests: (a) Equal welds; (b) and (c) proportional welds

Table 1. Results of Tensile Tests

\begin{tabular}{l|c|c|c}
\hline \multicolumn{2}{c|}{ Specimen type } & $\begin{array}{c}\text { Yield load, } \\
\text { tons }\end{array}$ & $\begin{array}{c}\text { Load at } \\
\text { fracture, tons }\end{array}$ \\
\hline Equal welds $\quad$ (Fig. 5a) & 86.30 & 154.00 \\
Proportional welds(Fig. 5b) & 93.00 & 155.20 \\
Proportional welds(Fig. 5c) & 94.00 & 155.00 \\
\hline
\end{tabular}

と唇かった。)

\section{4 併用隅肉熔接継手}

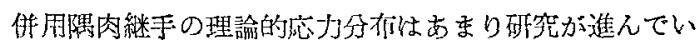

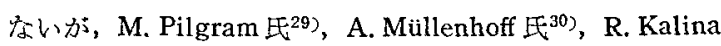
氏31などが研究結果を発表している，前面站よび側面隅肉 で用いた仮定とほぶ同様の仮定を用い，結局 $\cosh$ 型の塑 断応力行布式を得ている(M. Pilgram氏 ${ }^{30}$ ， R. Kalina氏 ${ }^{29}$

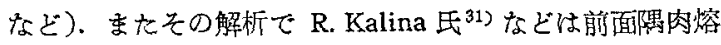
接住対して側面隅肉熔接 $\left(K_{S}\right)$ と怡別の Detrusion Ratio $\left(K_{F}\right)$ を考えて括り，耐 Detrusion Ratio は実験で決定す ベきものとしたが実際には測定していない。

併用隅肉継手の鱽度に関しては，併用隅肉熔接の中前面 隅肉熔接が伝達する荷重の割合 $(\boldsymbol{P})$ が閣題となる。主な理 諭的研究の結果柱次の如くである。

1）併用隅肉熔接の中前面隅肉熔接加伝達主る荷重の割 合を前面隅肉熔接の長さと 2 つの側面隅肉熔接の 1 つの長 さとの比の函数として示した（(M. Pilgram E $\left.{ }^{29}\right)$ ).

2）併用熔接にか心る菏重の大部召は，乙の前面隅肉熔 接が降伏与るまでは前面阳肉で伝墶され，降伏した後は全 荷重が側面隅肉で伝達される。したがって併用隅肉熔接は 側面隅肉熔接に対する許容重で設計するのが安全である (A. Müllenhoff $E^{30)}$ ).

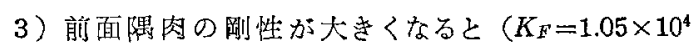
$\mathrm{kg} / \mathrm{mm}^{2}$ ), 前面隅肉の伝達する荷重の割合怡大となり，側 面隅肉の端部に括ける応力集中るまた大となる（R. Kalina 民31)，前面隅肉燃接は側面隅闪熔接の附加的な長さと見 做し得るという仮定（ドイツ整準施工法）に基いて計算し た結果に就して R. Kalina 氏の計算した能面陆肉の伝達す る荷重の割合は $\left(\mathrm{K}_{F}=0.7 \times 10^{4} \mathrm{~kg} / \mathrm{mm}^{2}\right.$ および $\mathrm{K}_{s}=0.7 \times$ $10^{4} \sim 2.11 \times 10^{4} \mathrm{~kg} / \mathrm{mm}^{2}$ として）50〜400\%大である.

以上のようにいずれる傾向としては一致して招り，実験 結果をまって正確な $\mathrm{P}$ の值を求めることが必要であるう.

応力分析実駼は竺来主として譏械的歪計が使われてきた が最近は電気的歪計が有才な測定法として用いられてい る. その他の方法には殆ど見るべきむのがない，実駼の絬 果は併用熔接は側面隅肉上り灾力集中が少なく灾力分布が よ(36)，特飞前面隅肉汶対して側面隅肉の辰い場合换言す れば荷重方向に対して細長い併用継手がよいようである。

また強度笑験ては次の様な結果が出ている。

1）併用售接の最大喉応力以側面哈よび前面隅肉の個々 の最大喉応力の平均䎲等しかった（H. J. Godfrey 顿よび

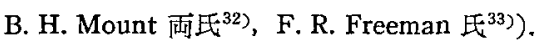

2）併用隅肉を設計する場合前面括よび側面の側面の個 タの強度を用いて前面括よび側面网肉を加算すれば安全で ある (K. P.S. Gardner 氏 $\left.{ }^{34}\right)$ ).

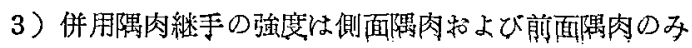




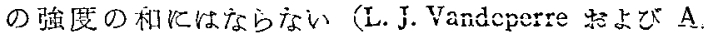
Joukoff 雨区 $\left.{ }^{35}\right)$ ).

3)の維諭方要当と考光られるが，これは能面隅肉が側面

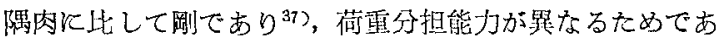
ろう.

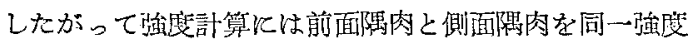
として一緒に加光ることは不合理で，前述の如き坷重分担 の割合や破堛态力の変化を考虑して合的理な計算を行うへ きである. しかし具体的数值を示す炕実駼デ一夕が不足 のようである、したがって併用隅肉の実用計算飞相加の法 則を度用すれば，熔着金属が必要以上飞や小大となる不利 はあるが設計性安全側となる。

併用隅肉熔接した補强当板に関して最近 2 つ研究が発 㤗されている。

日本造船研究協会 ${ }^{28}$ 壮広い板に併用隅肉熔接した二重张 (当板) の有效性括よ。 び店力分布関して 研究した. 第 6 困に 示す如き母材の板厚 を $t$ ，板幅を $b^{\prime} と 乙$ 併用熔接炕よってと りつ忛た二重张（当 板）の板厚を $t^{\prime}$ ，幅

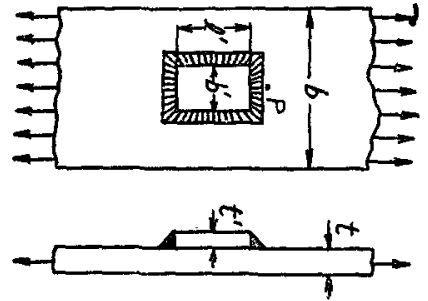

Fig 6 . を光，長さを $l^{\prime}$ 之す

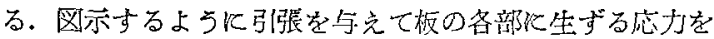
測定し次のような結果を得た，但し二重張の效きは次の二 重索考克た（第 7 図参照）。
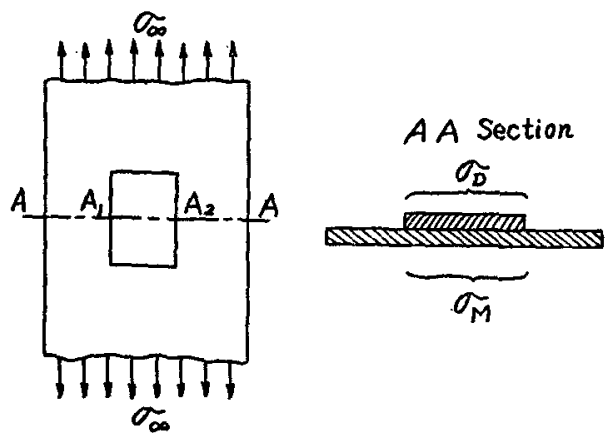

Fig 7.

A) 第 7 図以示す二重張の $A A$ 断面において二重倨表面 の応力の $A_{1}, A_{2}$ 間の平均值を $\sigma_{\Perp}$ として芯力分担比を次 のようと定義する.

応力行担比 $=\frac{\sigma_{D}}{\sigma_{M}}$

二重㖪の効きが良くなることは $\sigma_{M}=\sigma D$ となって分担比が 1に近らくことに相当する.

B）二重張をつける目的の一つ忹二重張部の母材の応力
を減らすことにあるからこの減少率を次のように定義す 索.

$$
\text { 因材応力減少率 }=\frac{\sigma^{\infty}-\sigma_{M}}{\sigma^{\infty}}
$$

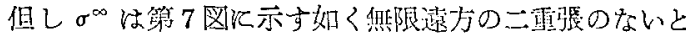
ころての引振応力である。

主要結坔

1）二琶張りの応力の流れ方を見ると，その有效性浊二 䨘張りの長厚比 $l^{\prime} / t^{\prime}$ と縦横比 $l^{\prime} / b^{\prime}$ 《よって沃まる.

2）長厚此が大なるときすなわち長い二重張りは有效で ある。

3）縦横比が大なるときすなかち外力の方问侅長い二重 张りは有效である。

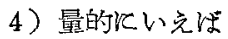

紑横比い1のときは鼠厚比20以上必要である。

緃横比が 2 のををには長厚比10以上必要である。

5）母材と二重張板の板厚比 $t^{\prime} / e$ は試験筑国内では まり影響吕ない，同㥞飞母材之の板幅比 $b^{\prime} / b$ 屯あまり影 響がない、いいか学る之二重留りの有効性は二重张板の形 と板厚で決ってくる.

6 ）第 6 図A点附近の二重㖘り止りには局部曲げが生し 板の表面忍力が増大し応力集中係数 1.7 K達することがあ る. 一般に二重張板の厚さが增する局部由げは增し，委た 二重張板の長さが増すと局部曲げが增加する。板幅はあま り影憵がない。

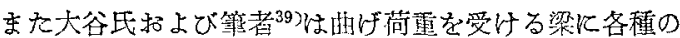

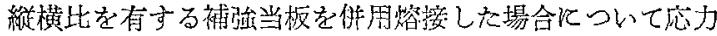
分布括よび当板の有效性を研究した。すなわ方前面隅肉近 くの主板には当板なしの場合に比し17 -65\%膏い応力が誘 起されるととを示し（このととは当板をつける場合の構造 設計で念れてなら点である），また当板の有效性（当板 の平均态力之梁理諭で計算した当板の応力值の比 $=\eta$ ) 注 その長さ $(L)$ が增すとともに大となり，板幅 $(B)$ の約 3 倍のとき $(L / B=3)$ ほ

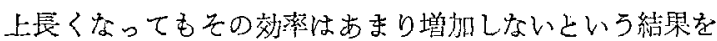
得应(策8图)。

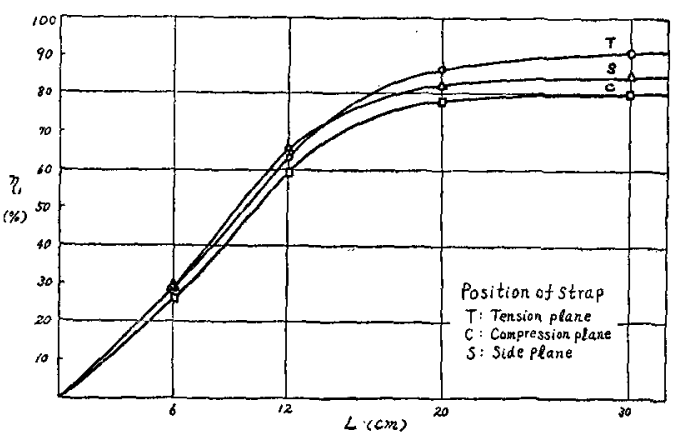

Fig 8. Efficiency of strap, $\varsigma_{1}=\sigma_{m} / \sigma_{s}\left(\mathrm{p}^{\prime}=5\right.$ ton $)$ 


\section{女献}

1) U. V. Gardena, Scientific Research Papers on Welding, All-Union Scientific Engg. Soc. of Welders, U.S.S.R., (2), 1936, 156-174

2) H. W. Troelsch, Trans. A.S.C.E., Nov. 1932

3) F. Bleich, Stahlhochbauten, Springer, Berlin, 1, 1932, 467-469

4) W. Hovgaard, Z.A.M.M., 11, 1931, 341-348; W. Hovgaard, Proc. Nat. Acad. Sci., 16, 1930, 666-678; 17, 1931, 351-359; Trans. Insti. Naval Arch., 73, 1931, 108-126

5) E. Callandreau, Compt. Rend., 196, 1933, 13671369

6) R. Kalina, Z.Ö.I.A.V., 85, 1933, 118-171

7) H. M. Mackay and A. M. Bain, Canadian J. Research, 3, 1930, 260-271

8) W. H. Weiskopf and M. Male, A.W.S.J., 9 (9), $1930,23-48 ; 9(12), 1930,68-82$

9) P. Fillunger, Österr. Wochenfchrift f. d. Öffentlich. Baudienst, 3, 1919

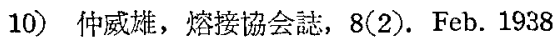

11) F. R. Freeman, Engineering, Feb. 1931, 192

12) H. E. Grove, Commonwealth Engineer, $15(9,12)$ 1928

13) E. Gaber, Bauing., 13(21-22), 1932, 290-294

14) Dept. Sci. \& Ind. Research, Great Britain, Second Report of Adhesives Research Ctttee., 1926, 104-106 ; Third Report of Adhesives Research Cttee., 1932, 36-42

15) E P.S. Gardner, Quarterly Trans. Inst. Welding, 2, 1939, 45-59

16) E. Höhn, The Strength of Doufle Lap Joints with Combined Side and End Welds, International Congress for Metallic Structures, Liége, 1930

17) S. Bryla, The Resistance of Lateral Welds to Shearing Stress, International Association for Bridge and Strucural Engineering, Publications, 2, 1934, 21-32

18) R. R. Blackwood, Commonwealth Engineer, 18 (2), $1930-31,50-55 ; 18(3), 89-97$
19) N.C. Kist, Preliminary Publication Intnl., Assn. Bridge \& Structural Engg., 1936, 511-522

20）武藤清，窑接協会誌，6(3)，May 1936

21) C. H. Lobban, Inst. Civ. Eng., Minuter of Proceedings, 231, 1930-1, 332-335

22) G. A. Hankins and A. F. C. Brown, Welding of Steel Structures, His Majesty's Stationegy Office, London , 1938, 33-164

23) P. J. Palmer, Brit. Weld. J., 2(2), Feb. 1955, 5560

24) 例えば交献

25) D. H. Wade, M. Sc. Thesis University of Birmingham, 1954

26) A. M, Mackie, Brit. Weld. J., 2(11), Nov. 1955, 501-503

27) F. Koenigsberger \& H. W. Green, Weld. J:; 32 (9), Sept. 1953, 859-863

28) F. Koenigsberger \& H. W. Green, Brit. Weld. J., 2(9), Sept. 1955, 369-372

29) M. Pilgram, Bauing., 12, 1931, 128-129

30) A. Müllenhoff, Bauing., 12, 1931, 333-335

31) R. Kalina, Stahlbau, 7, 1934, 97-100

32) H. J. Godfrey and B. H. Mount, Weld. J. 16 (4), $1940,133 \mathrm{~s}-136 \mathrm{~s}$

33) F. R. Freeman, Proc. Instn. Civil Engrs., 231, 1930/31, 283-304; A.W.S.J. 11(6), 1932, 16-24

34) K. P. S. Garder, Quarterly Trans. Inst. Welding, $2,1939,45-59$

35) L. J. Vandeperre and A. Joukoff, Le Calcul des Constructions Soudées, A. de Boeck, Brussels, 1939;

L. J. Vandeperre and J. de Myttenaere, Comptes Rend., (6), 1935, 126-164

36) G. Bierett, Elektroschw., 4, 1933, 21-27, 61-70, 94-97

37) Handbuch für die Ausführung Geschweisster Stahlbauten

38）日本造船研究協会第二研究部筍三小委買会，二重㟲 構造の有効性, $1953-10$

39）大谷 珵, 太田省三毁, 鉄道技術研究所中間報告, 5 (147)，1955-1 